\title{
Cognitive Placement Theory for Performance Appraisal: Talent Management and Individual Performance
}

\author{
Gürhan Uysal \\ Ondokuz Mayıs University, Samsun, Turkey
}

\begin{abstract}
This paper does search for talent management and individual performance. It believes that cognitive placement might be used for talent management to determine individual performers. Cognitive methodology assumes that HR manager replaces performance grade of employees into placement line. In upper case, it is grade of employees between 0 and 100. In lower case, it is percentage of performance sub-groups. HR managers replace the top $10 \%$ of grades into placement line. That group is talent management group. It is assumed that talent management is to appoint ability professionals for management positions. In addition, this study proposes that cognitive placement by HR managers may specify top performers (professionals) in organizations. Therefore, performance appraisal process is important in talent management, because talent management in HR is related with individual performance and management positions.
\end{abstract}

Keywords: talent management, individual performance, cognitive placement, HR managers

\section{Introduction}

Individual performance is important to talent management, because high performers may replace management positions in organizations. Considering this, this paper suggests that cognitive placement might be a method for determining high performers.

\section{Theory}

Who is HR in a company? The answer may be "professionals", white or pink, because they are candidates for management positions in organizational hierarchy. Therefore, HR of a firm might be workforce, professionals, and managers, as managers may have an impact on firm performance through department performance. A high performer manager may increase the performance of his department. The performance of all departments increases firm performance. It is the assumption of talent management. Therefore, it is important to determine individual performance.

Performance appraisal gains importance in talent management to determine individual performance. In addition, cognitive methodology might be used in performance appraisal process in order to determine individual performance.

\section{Talent Management: Definition}

Talent management is described with the appointment of professionals into management positions in

Gürhan Uysal, associate professor, School of Business, Ondokuz Mayıs University. Email: gurhanuysal@yahoo.com; uysal_g@omu.edu.tr. 
organizations. Firstly, HR is defined as the core competence of a firm. Core competence is the resource of organizations, and HR is the most key resource of organizations. It is unique and hard to imitate, because it is the intellectual capital, which is unique and hard to imitate. So, talents or human resources (professionals) may differentiate firm from rivals.

Secondly, HR is the intellectual capital of organizations, or intangible assets. Thus, it is resources.

Firms create national GDP in an economy. Its production and sales make up national GDP. Therefore, the appointment of white collars (or pink) into managerial positions may be important to the competitiveness of a country, because managers and business departments determine the performance of the firm, such as market share, sales, profit, and amount of production in the back. This means that if there are sales in markets, there would be production in firm's organizations, according to firm theory by Prof. Vasily Leontief, who is a winner of the Nobel Prize of Economy in 1973 with this theory.

\section{Cognitive Placement for Performance Appraisal}

The method of cognitive placement determines the performance groups among employees. HR managers appoint the performance grade of employees into one group. Top performers and bad performers are interested to HR managers, because top performers make up the "talent management" group and bad performers make up the "performance management" group. Talent performers might be candidates for management positions, because they have the best individual performance, while bad performers may need performance management process to upgrade their knowledge and individual performance. So, we make the scale of cognitive placement as follows (see Figure 1).

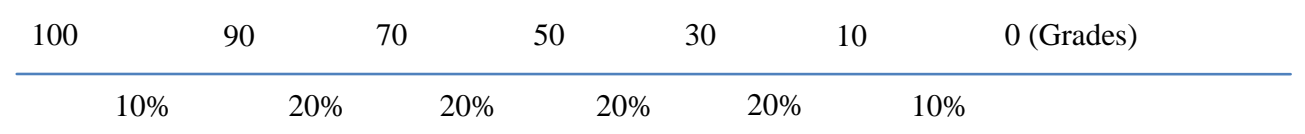

Figure 1. Cognitive placement line in performance appraisal.

Top individual performance has the performance grade of 90-100, while bad performance has the lowest grade of 10. In addition, the two groups might be the target group of HR managers and HR departments. HR manager replaces the top $10 \%$ of employees into top performers and replaces the lowest $10 \%$ of employees into bad performer group.

\section{Research Methodology}

Case study is used for this study. Case study might become an appropriate research methodology in HR field. For study purpose, a fictive case study is used in this study.

Think about Bexts Company which has 110 employees with four divisions as finance, accounting, production, and marketing. HR obtains performance results from those departments and HR manager replaces each performance grade into subgroups in cognitive placement line. Top and bad performance groups are important for HR managers. Because top represents talent group in succession planning and bad performers are performance development group.

In the second phase, HR manager overviews top and bad groups. Suppose that Mary, Michael, Tumato, and Nicky make up the top $10 \%$ in performance grade; and Henry, Claudia, and Thomas make up the lowest $10 \%$, according to managers’ performance evaluation. 
In the third phase, HR manager may develop succession planning, promotion planning, or career planning for best employees for managerial positions, as they are talented and they are candidates for becoming managers in the near future. While for bad performers, human resource management (HRM) departments may develop performance development plans for bad performing group in order to increase their individual performance. For example, HR managers may organize coaching behaviors for bad performers, or HR managers determine rotation plans or enroll MBA programs in universities.

\section{Findings}

The findings of this study are that individual performance is important in talent management and cognitive placement methodology may determine individual performance of employees. Individual performance specifies career planning for companies. Thus, firms may implement cognitive placement methodology in order to determine individual performance of their professionals.

\section{Personnel HRM: Jobs to Employees}

Secondly, this paper supposes that HRM is the continuing of personnel management (PM). In traditional chronology, PM departments were established in the 1930s in firms, after Frederick Taylor and colleagues' efforts. Further, HRM department was established in the 1980s in organizations. HRM took over some practices of PM such as career, talent, performance, staffing, training, etc.. Therefore, HRM may be supposed as the continuing of PM practices. Currently, PM implements employee affair issues in organizations and those works take huge amount of time of HR professionals.

PM continues as daily activities currently. It takes enormous time of HR professionals, and HRM implements previous PM practices. PM is related with employee affairs. In addition, PM is related with jobs in organizations. Jobs are such as accounting, marketing, manufacturing, finance, stocks, supply, etc.. PM advises employees to carry out these jobs. HRM is associated with employee performance. HRM aims to increase employee performance through positive organizational attitudes and behaviors. HRM implements earlier practices of PM to increase individual performance. Those practices are career management, compensation, training, talent management, etc..

The notion of personnel HRM is the combination of PM and HRM. For this case, PM implements employee affairs and HRM implements HRM practices. This is currently the case of companies. HRM departments of firms do employee affairs and HRM practices together. Thus, we have the following formula:

\section{Personnel HRM = Employee affairs + HRM practices}

HRM departments implement such formula to have an impact on individual performance of employees.

To conclude, the difference between PM and HRM is viewpoint difference against personnel. PM is autocratic and pressure, while HRM is autonomous for employees. Further, PM forces workers to accomplish organizational jobs such as finance, logistics, marketing, accounting, supply, and others. Doing jobs achieves firm performance, PM proclaims. HRM aims to increase employee efficiency at jobs. That point might be the viewpoint difference between PM and HRM. 


\section{Conclusion}

Cognitive placement methodology might be used by HRM departments in order to determine individual performance, because individual performers might become candidates for management positions.

This study specifies three contributions for academics:

(1) Who is HR in organizations?

(2) HR is the core competence of organizations.

(3) Cognitive placement methodology might be used by HRM departments to determine individual performance.

\section{References}

Uysal, G. (2007). Do firms employ application form in staffing process? Paper presented at the 22nd Workshop on Strategic Human Resource Management, European Institute for Advanced Studies in Management, Brussels, Belgium, May 22-23.

Uysal, G. (2008). Human resource management in the US, Europe and Asia: Convergence towards HRM policies and divergence in HRM practices? Paper presented at the 23rd Workshop on Strategic Human Resource Management, University of Ljubljana, Slovenia, April 3-4.

Uysal, G. (2010). HR system is correlated inside? Relationship of HRM practices. Paper presented at the 25th Workshop on Strategic Human Resource Management, ESADE Business School, Barcelona, Spain, April 19-20.

Uysal, G. (2011). Human resource focus in TQM awards. Paper presented at the 26th Workshop on Strategic Human Resource Management, University of Reykjavik, Iceland, May 16-17.

Uysal, G. (2012). Europe 2020 strategy: PPP model to cobweb theorem in cluster innovation. Paper presented at the 27th Workshop on Strategic Human Resource Management, European Institute for Advanced Studies in Management, Brussels, Belgium, April 12-13.

Uysal, G. (2013). Progress of HRM into SHRM: Human resources as capital. Paper presented at the 28th Workshop on Strategic Human Resource Management, Copenhagen Business School, Copenhagen, Denmark, April 15-16.

Uysal, G. (2016). Cognitive placement theory for performance appraisal: Talent management and individual performance. Paper presented at the 31st Workshop on Strategic Human Resource Management (submission). 